\title{
The Use of Germination Indices for Salinity Tolerance Classification of Pepper Cultivars
}

\begin{abstract}
Gamze Kaya ${ }^{1, a, *}$
${ }^{1}$ Republic of Turkey Ministry of Agriculture and Forestry, Eskişehir Directorate of Provincial Agriculture and Forestry, 26020 Odunpazarı/Eskişehir, Turkey

*Corresponding author

\begin{tabular}{|c|c|}
\hline A R T I C L E IN F O & A B S T R A C T \\
\hline $\begin{array}{l}\text { Keywords: } \\
\text { Capsicum annum } \mathrm{L} \text {. } \\
\mathrm{NaCl} \\
\text { Cultivar } \\
\text { Germination indices } \\
\text { Seedling growth }\end{array}$ & $\begin{array}{l}\text { The study aimed to evaluate the use of germination indices as a screening tool for salinity tolerance } \\
\text { during germination and early seedling growth of pepper cultivars, and to distinguish the potential } \\
\text { for genetic responses to salt tolerance. In the study, the seeds of seven pepper cultivars were } \\
\text { germinated at increasing } \mathrm{NaCl} \text { levels of } 5,10,15 \text { and } 20 \mathrm{dS} / \mathrm{m} \text { and distilled water as the control } \\
\text { treatment for } 14 \text { days. Germination percentage (GP), mean germination time (MGT), germination } \\
\text { index (GI), germination stress tolerance index (GSTI), seedling length (SL), seedling fresh weight } \\
\text { (SFW) and vigor index (VI) were investigated. Results showed that germination percentage } \\
\text { decreased with increasing NaCl levels while the highest germination percentage at } 20 \mathrm{dS} / \mathrm{m} \text { was } 92 \% \\
\text { in BT Burdem with no significant reduction. Seedling growth of pepper cultivars was severely } \\
\text { inhibited by increasing salinity stress. SFW was depressed depending on reduction in SL due to } \\
\text { increasing NaCl. BT-Burli and BT Ince Sivri were the most tolerant cultivars to NaCl and they were } \\
\text { used for genetic resources towards salinity. Seedling growth was much more sensitive to salinity } \\
\text { than germination because of the highest percent reduction in seedling growth parameters. Among } \\
\text { the parameters, GSTI gave the highest significant correlation coefficient with SL and SFW; } \\
\text { indicating that it would be useful for estimating seedling growth. It was concluded that genotypic } \\
\text { variation was observed among pepper cultivars for salinity tolerance and GSTI could be used for a } \\
\text { predictor for salinity tolerance. }\end{array}$ \\
\hline
\end{tabular}
\end{abstract}

pascalcik@hotmail.com

(iD) https://orcid.org/0000-0002-9815-2672|

(c) (1) () This work is licensed under Creative Commons Attribution 4.0 International License

\section{Introduction}

Several abiotic stress factors like low and high temperature, salinity and drought negatively affect the final percentage and speed of germination; consequently, they may lead to irregular emergence and stand establishment (Foolad et al., 1999). Among these stresses, salinity is the most severe factor for crop plant during the whole life cycle because it inhibits the water uptake by plants due to osmotic pressure and causes the ion toxicity (Almansouri et al., 2001; Okçu et al., 2005).

Pepper is sensitive or moderately sensitive to salinity during different growth stages as reported by several authors (Bethke and Drew, 1992; Gunes et al., 1996; Pascale et al., 2003). It is more sensitive to salinity during germination and early seedling growth while some cultivars are more tolerant to salinity than the others (Chartzoulakis and Klapaki, 2000). Salinity is responsible for the reduction in germination and inhibition in the initial seedling development of the pepper (Y1lmaz et al., 2004).

The breeding of salt-tolerant crops is the most effective way to overcome salinity problem with financial feasibility and time saving manner. However, there are relative differences in salinity tolerance among the species and cultivars within certain species (Foolad and Lin, 1997; Chartzoulakis and Klapaki, 2000; Murillo-Amador et al., 2001). Screening of genetic variation in a species is the first step of the breeding program and thereafter selection of proper genotypes is done. The earlier researches on salinity tolerance of pepper showed that the germination and seedling growth were severely affected but the genotypic variation existed. Y1lmaz et al. (2004) reported that the germination performance of 11 pepper cultivars significantly reduced with the increasing of $\mathrm{NaCl}$ levels from $0 \mathrm{mM}$ to $150 \mathrm{mM}$ and Aktas et al. (2006) determined salt-tolerant and salt-sensitive genotypes at seedling stage among 102 genotypes. This study aimed to determine the responses of pepper cultivars to $\mathrm{NaCl}$ during the germination by means of several indices and early seedling growth by vigor index and percent reduction, and to detect the genetic diversity in pepper cultivars for salinity tolerance. 


\section{Materials and Methods}

Seven pepper cultivars extensively marketing for green fruit production, BT Burli, BT Demok, BT İnce Sivri, BT Burkalem, BT Burdem, Yalova Yağlık 28 and Yalova Çarliston were used as material. Germination and early seedling growth of the cultivars were investigated under distilled water (control) and several $\mathrm{NaCl}$ concentrations with the electrical conductivities (EC) of 5, 10, 15 and 20 $\mathrm{dS} / \mathrm{m}$.

For germination test, four replicates of 50 seeds from each cultivar were germinated between three layered filter papers moistened with $21 \mathrm{~mL}$ of respective test solutions. After the papers were rolled, they were placed into sealed plastic bags to avoid moisture evaporation. To prevent salt accumulation, the papers were renewed every 2 days. The germination test was conducted at $25 \pm 1^{\circ} \mathrm{C}$ under darkness. A radicle elongation of $2 \mathrm{~mm}$ was considered as germination criterion. The seeds germinated were counted every $24 \mathrm{~h}$ for 14 days to determine germination percentage (GP) and mean germination time (MGT). MGT was calculated for the speed of germination according to ISTA (2003). Seedling length (SL) and seedling fresh weight (SFW) of 10 seedlings randomly selected from each replicate were measured after 14 days.

Seedling vigor index (VI) was calculated by multiplying the germination percentage $(\%)$ and seedling length $(\mathrm{cm})$.

Germination index (GI) was determined as the number of germinated seeds / days after planting $+\ldots .+$ no. of germinated seeds / days of final count (Salahzade et al., 2009).

Germination stress tolerance index $(\mathrm{GSTI})=\left[\left(\mathrm{nd}_{2} \times 1\right)\right.$ $+\left(\mathrm{nd}_{4} \times 0.75\right)+\left(\mathrm{nd}_{6} \times 0.50\right)+\left(\mathrm{nd}_{8} \times 0.25\right)$ in stressed seeds $) /\left(\mathrm{nd}_{2} \times 1\right)+\left(\mathrm{nd}_{4} \times 0.75\right)+\left(\mathrm{nd}_{6} \times 0.50\right)+\left(\mathrm{nd}_{8} \times\right.$ 0.25) in control seeds] (Ahmad et al., 2009), which indicates the salinity tolerance, and $\mathrm{nd}_{2}, \mathrm{nd}_{4}, \mathrm{nd}_{6}$, and $\mathrm{nd}_{8}$ represent the number of seeds germinated on day $2,4,6$, and 8 respectively.

Percent reduction was calculated as $\mathrm{PR}=100-[$ (stress value at each $\mathrm{NaCl}$ level / control value) $\times 100$ ] .

The experimental design was two factors factorial arranged in a completely randomized design with four replicates. Data for germination percentage were subjected to arcsine transformation before ANOVA was performed using MSTAT-C program (Michigan State University). The differences between the means were compared with LSD values $(\mathrm{P}<0.05)$.

\section{Results}

A two-way interaction (cultivar $\times$ salinity level) was significant $(\mathrm{P}<0.05)$ for all investigated characters (Table 1). GP was statistically changed by cultivars and $\mathrm{NaCl}$ doses. The minimum germination among the cultivars was determined in BT Burkalem with $67.3 \%$. Increasing electrical conductivity by $\mathrm{NaCl}$ resulted in a significant delay in MGT. GI also reduced from 11.20 to 4.84, while GSTI, seedling length (SL), seedling fresh weight (SFW) and VI decreased when $\mathrm{NaCl}$ levels were increased. Among the pepper cultivars, BT Burli gave the highest mean values in all characteristics.

The interaction of cultivar $\times \mathrm{NaCl}$ levels showed a significant effect $(\mathrm{p}<0.05)$ on GP (Table 2). The higher level of $\mathrm{NaCl}$ than $5 \mathrm{dS} / \mathrm{m}$ significantly reduced $\mathrm{GP}$ of pepper cultivars and the maximum germination at $20 \mathrm{dS} / \mathrm{m}$ was recorded in BT Burdem with $92.0 \%$ and BT Burli $(91.0 \%)$, respectively. The least affected pepper cultivar from $\mathrm{NaCl}$ was $\mathrm{BT}$ İnce Sivri because of no decrease in GP. Among the pepper cultivars, BT Burkalem was the most $\mathrm{NaCl}$ sensitive genotype at the germination stage due to the highest percent reduction.

Table 1 Analysis of variance and main effects of $\mathrm{NaCl}$ levels on the investigated traits of pepper cultivars

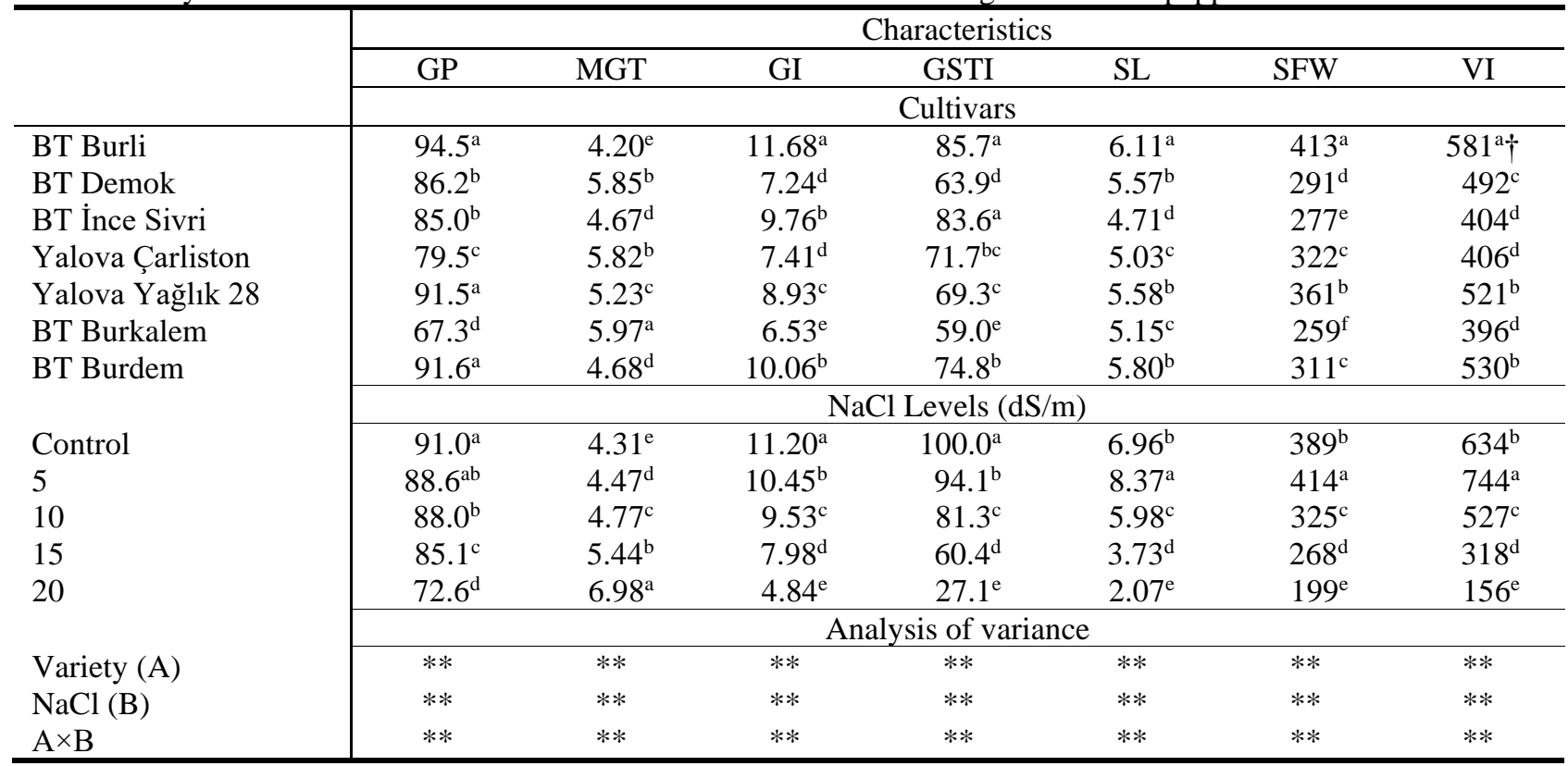

**: significant at $\mathrm{P}<0.01 \dagger$ : Means followed by same letter(s) in each column are not significant at $\mathrm{P}<0.05$. GP: Germination percentage, MGT: Mean germination time, GI: Germination index, GSTI: Germination stress tolerance index, SL: Seedling length, SFW: Seedling fresh weight, VI: Vigor index 
Table 2 Changes in germination percentage (\%) of pepper cultivars affected by $\mathrm{NaCl}$ levels

\begin{tabular}{l|rrrrrr}
\hline \multirow{2}{*}{ Cultivars } & \multicolumn{5}{c}{$\mathrm{NaCl}$ levels $(\mathrm{dS} / \mathrm{m})$} \\
\cline { 2 - 6 } & Control & \multicolumn{1}{c}{10} & \multicolumn{1}{c}{15} & 20 & Reduction $(\%)$ \\
\hline BT Burli & $98.5^{\mathrm{a}}$ & $94.5^{\mathrm{ab}}$ & $94.5^{\mathrm{ab}}$ & $94.0^{\mathrm{abc}}$ & $91.0^{\mathrm{a}-\mathrm{f} *}$ & -7.6 \\
BT Demok & $89.0^{\mathrm{a}-\mathrm{f}}$ & $89.5^{\mathrm{a}-\mathrm{f}}$ & $94.5^{\mathrm{ab}}$ & $90.0^{\mathrm{a}-\mathrm{f}}$ & $68.0^{\mathrm{h}}$ & -23.6 \\
BT İnce Sivri & $83.5^{\mathrm{c}-\mathrm{g}}$ & $89.0^{\mathrm{a}-\mathrm{f}}$ & $87.0^{\mathrm{b}-\mathrm{f}}$ & $82.0^{\mathrm{efg}}$ & $83.5^{\mathrm{c}-\mathrm{g}}$ & 0.0 \\
Yalova Çarliston & $87.0^{\mathrm{b}-\mathrm{f}}$ & $81.0^{\mathrm{fg}}$ & $80.5^{\mathrm{fg}}$ & $81.0^{\mathrm{fg}}$ & $68.0^{\mathrm{h}}$ & -21.8 \\
Yalova Yağlık 28 & $96.0^{\mathrm{ab}}$ & $93.5^{\mathrm{a}-\mathrm{d}}$ & $95.5^{\mathrm{ab}}$ & $91.0^{\mathrm{a}-\mathrm{f}}$ & $81.5^{\mathrm{efg}}$ & -15.1 \\
BT Burkalem & $87.5^{\mathrm{b}-\mathrm{f}}$ & $83.0^{\mathrm{d}-\mathrm{g}}$ & $74.5^{\mathrm{gh}}$ & $67.0^{\mathrm{h}}$ & $24.5^{\mathrm{i}}$ & -72.0 \\
BT Burdem & $95.5^{\mathrm{ab}}$ & $90.0^{\mathrm{a}-\mathrm{f}}$ & $89.5^{\mathrm{a}-\mathrm{f}}$ & $91.0^{\mathrm{a}-\mathrm{f}}$ & $92.0^{\mathrm{a}-\mathrm{e}}$ & -3.7 \\
Reduction $(\%)$ & - & -2.6 & -3.3 & -6.5 & -20.1 & -1 \\
\hline
\end{tabular}

*: Means followed by the same superscript letter(s) are not significantly different at $\mathrm{P}<0.05$ level

Table 3 Changes in mean germination time (day) of pepper cultivars affected by $\mathrm{NaCl}$ levels

\begin{tabular}{l|rrrrr}
\hline \multirow{2}{*}{ Cultivars } & \multicolumn{5}{c}{$\mathrm{NaCl} \mathrm{levels}(\mathrm{dS} / \mathrm{m})$} \\
\cline { 2 - 6 } & Control & 5 & 10 & 15 & 20 \\
\hline BT Burli & $3.66^{\mathrm{uv}}$ & $3.61^{\mathrm{v}}$ & $4.00^{\mathrm{st}}$ & $4.24^{\mathrm{pqr} *}$ & $5.49^{\mathrm{hi}}$ \\
BT Demok & $4.94^{\mathrm{lm}}$ & $5.22^{\mathrm{jk}}$ & $5.54^{\mathrm{gh}}$ & $6.31^{\mathrm{d}}$ & $7.23^{\mathrm{b}}$ \\
BT İnce Sivri & $3.83^{\mathrm{tu}}$ & $4.11^{\mathrm{rs}}$ & $4.36^{\mathrm{opq}}$ & $4.67^{\mathrm{n}}$ & $6.37^{\mathrm{d}}$ \\
Yalova Çarliston & $5.07^{\mathrm{kl}}$ & $5.25^{\mathrm{jk}}$ & $5.32^{\mathrm{ij}}$ & $6.27^{\mathrm{d}}$ & $7.19^{\mathrm{b}}$ \\
Yalova Yağlı 28 & $4.40^{\mathrm{opq}}$ & $4.46^{\mathrm{o}}$ & $4.83^{\mathrm{mn}}$ & $5.69^{\mathrm{fg}}$ & $6.77^{\mathrm{c}}$ \\
BT Burkalem & $4.43^{\mathrm{op}}$ & $4.47^{\mathrm{o}}$ & $4.90^{\mathrm{lm}}$ & $6.05^{\mathrm{e}}$ & $-^{\mathrm{a}}$ \\
BT Burdem & $4.07^{\mathrm{rs}}$ & $4.20^{\mathrm{qr}}$ & $4.45^{\mathrm{op}}$ & $4.86^{\mathrm{lmn}}$ & $5.81^{\mathrm{f}}$ \\
\hline
\end{tabular}

*: Means followed by the same superscript letter(s) are not significantly different at $\mathrm{P}<0.05$ level

Table 4 Changes in germination index of pepper cultivars affected by $\mathrm{NaCl}$ levels

\begin{tabular}{l|rrrrr}
\hline \multirow{2}{*}{ Cultivars } & \multicolumn{5}{c}{$\mathrm{NaCl} \mathrm{levels}(\mathrm{dS} / \mathrm{m})$} \\
\cline { 2 - 6 } & Control & 5 & 10 & 15 & 20 \\
\hline BT Burli & $13.68^{\mathrm{a}}$ & $13.40^{\mathrm{a}}$ & $11.88^{\mathrm{b}}$ & $11.18^{\mathrm{bcd}}$ & $8.28^{\mathrm{hij} *}$ \\
BT Demok & $9.57^{\mathrm{fg}}$ & $8.93^{\mathrm{gh}}$ & $8.77^{\mathrm{ghi}}$ & $6.15^{\mathrm{lm}}$ & $2.77^{\mathrm{o}}$ \\
BT İnce Sivri & $11.81^{\mathrm{b}}$ & $11.46^{\mathrm{bc}}$ & $10.20^{\mathrm{ef}}$ & $8.74^{\mathrm{ghi}}$ & $6.58^{1}$ \\
Yalova Çarliston & $10.24^{\mathrm{ef}}$ & $8.27^{\mathrm{hij}}$ & $7.78^{\mathrm{j}}$ & $6.87^{\mathrm{kl}}$ & $3.86^{\mathrm{n}}$ \\
Yalova Yağlık 28 & $11.19^{\mathrm{bcd}}$ & $10.79^{\mathrm{cde}}$ & $10.90^{\mathrm{ef}}$ & $8.02^{\mathrm{ij}}$ & $4.56^{\mathrm{n}}$ \\
BT Burkalem & $10.11^{\mathrm{ef}}$ & $9.54^{\mathrm{fg}}$ & $7.51^{\mathrm{jk}}$ & $5.48^{\mathrm{m}}$ & $-\mathrm{p}$ \\
BT Burdem & $11.81^{\mathrm{b}}$ & $10.77^{\mathrm{cde}}$ & $10.47^{\mathrm{de}}$ & $9.43^{\mathrm{fg}}$ & $7.80^{\mathrm{j}}$ \\
\hline
\end{tabular}

*: Means followed by the same superscript letter(s) are not significantly different at $\mathrm{P}<0.05$ level

Table 5 Changes in seedling length $(\mathrm{cm})$ of pepper cultivars affected by $\mathrm{NaCl}$ levels

\begin{tabular}{l|rrrrrr}
\hline \multirow{2}{*}{ Cultivars } & \multicolumn{5}{c}{$\mathrm{NaCl}$ levels $(\mathrm{dS} / \mathrm{m})$} \\
\cline { 2 - 6 } & Control & 5 & 10 & 15 & \multicolumn{1}{c}{20} & Reduction $(\%)$ \\
\hline BT Burli & $7.36^{\mathrm{de}}$ & $8.88^{\mathrm{a}}$ & $6.85^{\mathrm{e}-\mathrm{h}}$ & $4.77^{\mathrm{kl}}$ & $2.69^{\text {op* }}$ & -63.5 \\
BT Demok & $7.26^{\mathrm{def}}$ & $8.70^{\mathrm{a}}$ & $6.37^{\mathrm{hij}}$ & $2.93^{\mathrm{o}}$ & $2.57^{\text {opq }}$ & -64.6 \\
BT İnce Sivri & $6.63^{\mathrm{f}-\mathrm{i}}$ & $7.20^{\mathrm{d}-\mathrm{g}}$ & $5.16^{\mathrm{k}}$ & $2.99^{\mathrm{o}}$ & $1.56^{\mathrm{rs}}$ & -76.5 \\
Yalova Çarliston & $6.08^{\mathrm{ij}}$ & $7.81^{\mathrm{cd}}$ & $4.84^{\mathrm{kl}}$ & $4.28^{\mathrm{lm}}$ & $2.15^{\mathrm{pqr}}$ & -64.6 \\
Yalova Yağlık 28 & $7.70^{\mathrm{cd}}$ & $9.30^{\mathrm{a}}$ & $5.82^{\mathrm{j}}$ & $3.09^{\text {no }}$ & $1.95^{\mathrm{prs}}$ & -74.7 \\
BT Burkalem & $6.52^{\mathrm{ghi}}$ & $8.05^{\mathrm{bc}}$ & $6.18^{\mathrm{hij}}$ & $3.69^{\mathrm{mn}}$ & $1.32^{\mathrm{s}}$ & -79.7 \\
BT Burdem & $7.14^{\mathrm{d}-\mathrm{g}}$ & $8.64^{\mathrm{ab}}$ & $6.61^{\mathrm{f}-\mathrm{i}}$ & $4.35^{\mathrm{l}}$ & $2.26^{\mathrm{pq}}$ & -68.3 \\
Reduction $(\%)$ & - & +20.3 & -14.1 & -46.4 & -70.3 & \\
\hline
\end{tabular}

*: Means followed by the same superscript letter(s) are not significantly different at $\mathrm{P}<0.05$ level

Increasing $\mathrm{NaCl}$ levels delayed time to germination of pepper cultivars (Table 3). In general, salinity level of 5 $\mathrm{dS} / \mathrm{m}$ did not clearly influence MGT while the higher levels of $\mathrm{NaCl}$ were much more effective for retardation in germination time. It is argued that the salinity influences on water absorption, reduces the osmotic potential of the medium; consequently, it inhibits the water uptake of the seeds (Jeannette et al., 2002).

Germination index is slightly decreased by lower levels of $\mathrm{NaCl}$ between control and $10 \mathrm{dS} / \mathrm{m}$ along with the pepper cultivars (Table 4). BT Burkalem did not emerge enough germination at $20 \mathrm{dS} / \mathrm{m}$, GI could not be calculated.
The highest GI was obtained from BT-Burli at all levels of $\mathrm{NaCl}$, while BT-Burkalem gave the minimum value of GI at $10 \mathrm{dS} / \mathrm{m}$ and above.

Increasing $\mathrm{NaCl}$ levels resulted in a reduction in $\mathrm{SL}$ of pepper cultivars; however, $5 \mathrm{dS} / \mathrm{m}$ of $\mathrm{NaCl}$ promoted the seedling growth (Table 5). At the highest level of $\mathrm{NaCl}$, BT-Burli showed the better seedling growth than the others, and it was followed by BT-Demok and BT-Burdem. Depending on increasing salinity levels, the least affected pepper cultivar was BT-Burli with $63.5 \%$ of reduction. The maximum percent reduction was observed in BTBurkalem with $79.7 \%$. 
Table 6 Changes in seedling fresh weight ( $\mathrm{mg} /$ plant) of pepper cultivars affected by $\mathrm{NaCl}$ levels

\begin{tabular}{l|rrrrrr}
\hline \multirow{2}{*}{ Cultivars } & \multicolumn{5}{c}{ NaCl levels $(\mathrm{dS} / \mathrm{m})$} \\
\cline { 2 - 6 } & Control & 5 & 10 & 15 & 20 & Reduction $(\%)$ \\
\hline BT Burli & $477^{\mathrm{b}}$ & $526^{\mathrm{a}}$ & $436^{\mathrm{c}}$ & $363^{\mathrm{efg}}$ & $261^{\text {no* }}$ & -45.3 \\
BT Demok & $371^{\mathrm{def}}$ & $390^{\mathrm{de}}$ & $303^{\mathrm{jkl}}$ & $199^{\mathrm{pq}}$ & $194^{\mathrm{pq}}$ & -47.7 \\
BT İnce Sivri & $318^{\mathrm{ijk}}$ & $338^{\mathrm{ghi}}$ & $289^{\mathrm{k}-\mathrm{n}}$ & $254^{\mathrm{o}}$ & $185^{\mathrm{q}}$ & -41.8 \\
Yalova Çarliston & $400^{\mathrm{d}}$ & $435^{\mathrm{c}}$ & $297^{\mathrm{klm}}$ & $269^{\mathrm{mno}}$ & $207^{\mathrm{pq}}$ & -48.2 \\
Yalova Yağlik 28 & $463^{\mathrm{bc}}$ & $469^{\mathrm{b}}$ & $382^{\mathrm{def}}$ & $289^{\mathrm{k}-\mathrm{n}}$ & $204^{\mathrm{pq}}$ & -55.9 \\
BT Burkalem & $328^{\mathrm{hij}}$ & $352^{\text {fgh }}$ & $255^{\mathrm{o}}$ & $224^{\mathrm{p}}$ & $134^{\mathrm{r}}$ & -59.1 \\
BT Burdem & $367^{\mathrm{efg}}$ & $389^{\mathrm{de}}$ & $316^{\mathrm{ijk}}$ & $379^{\mathrm{l}-\mathrm{o}}$ & $207^{\mathrm{pq}}$ & -43.6 \\
Reduction $(\%)$ & - & +6.43 & -16.5 & -31.1 & -48.8 & \\
\hline
\end{tabular}

*: Means followed by the same superscript letter(s) are not significantly different at $\mathrm{P}<0.05$ level

Table 7 Correlation coefficients (r) between the investigated characteristics of pepper cultivars

\begin{tabular}{|c|c|c|c|c|c|c|}
\hline & GP & MGT & GI & GSTI & SL & SFW \\
\hline MGT & $-0.763 * *$ & - & - & - & - & - \\
\hline GI & $0.795^{* *}$ & $-0.950 * *$ & - & - & - & - \\
\hline GSTI & $0.633 * *$ & $-0.876^{* *}$ & $0.904 * *$ & - & - & - \\
\hline SL & $0.454 * *$ & $-0.731 * *$ & $0.735 * *$ & $0.830 * *$ & - & - \\
\hline SFW & $0.567 * *$ & $-0.745 * *$ & $0.807 * *$ & $0.811^{* *}$ & $0.871 * *$ & - \\
\hline VI & $0.571 * *$ & $-0.767 * *$ & $0.805 * *$ & $0.854 * *$ & $0.982 * *$ & $0.901 * *$ \\
\hline
\end{tabular}

GP: Germination percentage, MGT: Mean germination time, GI: Germination index, GSTI: Germination stress tolerance index, SL: Seedling length, SFW: Seedling fresh weight, VI: Vigor index

As expected, $\mathrm{NaCl}$ levels had a significant effect on the SFW of all pepper cultivars (Table 6). Depending on decreasing SL due to $\mathrm{NaCl}$, SFW declined in all cultivars, but the reduction in BT İnce Sivri and BT Burli was lower than that in BT Burkalem and Yalova Yağlık 28. BT Burkalem gave a lower SL and this was attributed to lower SFW at higher salinity levels. The most affected cultivars, BT Burkalem and Yalova Yağlık 28, had the highest percent reduction values with $59.1 \%$ and $55.9 \%$, respectively.

The cultivar with the higher VI is evaluated to be more vigorous (Abdul-Baki and Anderson, 1973). In our study, the VI of pepper cultivars was adversely diminished by $\mathrm{NaCl}$, but the $\mathrm{NaCl}$ level of $5 \mathrm{dS} / \mathrm{m}$ slightly enhanced it depending on seedling growth (Figure 1a). Higher levels than $5 \mathrm{dS} / \mathrm{m}$ considerably decreased the VI of pepper cultivars and reached the minimum value at $20 \mathrm{dS} / \mathrm{m}$. Among the cultivars, VI of BT-Burli was clearly superior to other pepper cultivars at all levels of salinity.

In terms of GSTI, cultivar $\times \mathrm{NaCl}$ levels were significant and, it was severely affected by increasing levels of $\mathrm{NaCl}$. No significant change was observed up to $5 \mathrm{dS} / \mathrm{m}$ while higher $\mathrm{NaCl}$ levels led to significant reduction in GSTI (Figure 1b). BT İnci Sivri was not significantly affected up to $10 \mathrm{dS} / \mathrm{m}$. At $\mathrm{NaCl}$ levels of 15 and $20 \mathrm{dS} / \mathrm{m}$, BT Burli was distinguished by the GSTI.

Simple correlation coefficients calculated between germination characteristics and seedling growth showed that GSTI gave the highest positive correlation coefficient with SL $\left(\mathrm{r}=0.830^{* *}\right)$ and SFW ( $\left.\mathrm{r}=0.811^{* *}\right)$. MGT was negative and significantly correlated with other traits. The results indicated that seedling growth under $\mathrm{NaCl}$ stress could be forecasted by GSTI.

\section{Discussion}

Seed germination and initial seedling growth of pepper cultivars were obviously reduced by increasing salinity levels; however, the cultivars showed different responses to salinity. The germination percentage decreased and mean germination time increased when $\mathrm{NaCl}$ levels were increased; with varying responses by cultivars. No significant changes in germination of BT İnce Sivri was determined while $\% 72$ reduction on the germination of $\mathrm{cv}$. BT-Burkalem was observed. Similar results are reported by the observations of Turhan and Seniz (2010) in tomato, Yıldırım and Güvenç (2006) and Zhani et al. (2012) in pepper, who found that the salinity stress caused a decrease in germination percentage along with varying responses among the genotypes. The main effect of salinity was retardation in the time to germination and the seeds of all cultivars were more slowly germinated under $\mathrm{NaCl}$ than that of the control. Chartzaulakis and Klapaki (2000) and Yıldırım and Güvenç (2006) reported a delayed germination of pepper genotypes exposed to salinity. Furthermore, germination index and germination stress tolerance index of the cultivars were clearly diminished. These index values were the highest in BT-Burli while the minimum values were obtained in Bt-Burkalem. In addition, vigor index declined with increasing salinity. These indices were found as a good indicator for selecting drought tolerance (Shahverdikandi et al., 2011), salinity (Aflaki et al., 2017) and seed invigoration (Al-Ansari and Ksiksi, 2016). In addition, their relationship was positive and significant with seedling growth parameters of pepper cultivars. This finding shows that these indices should be used for predicting early seedling development. 


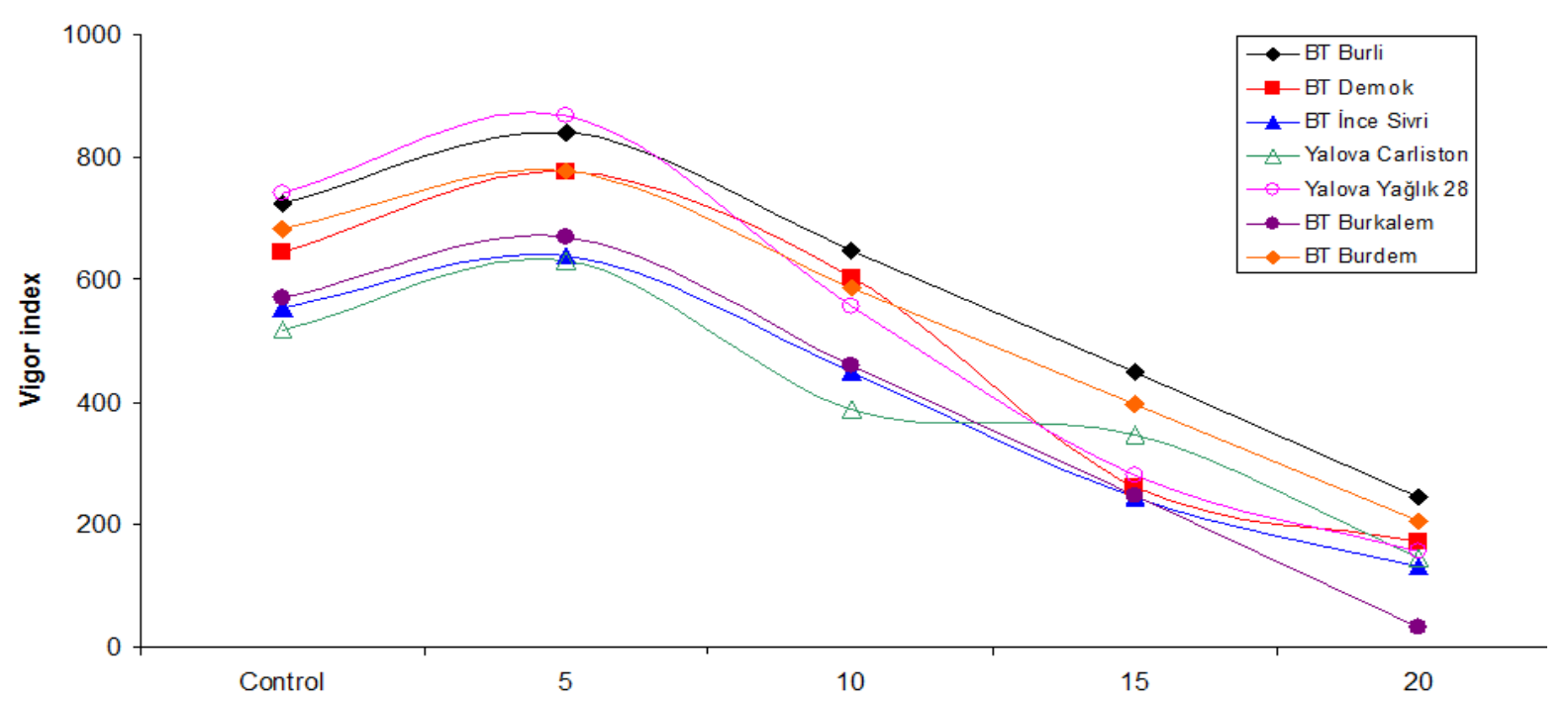

(a)

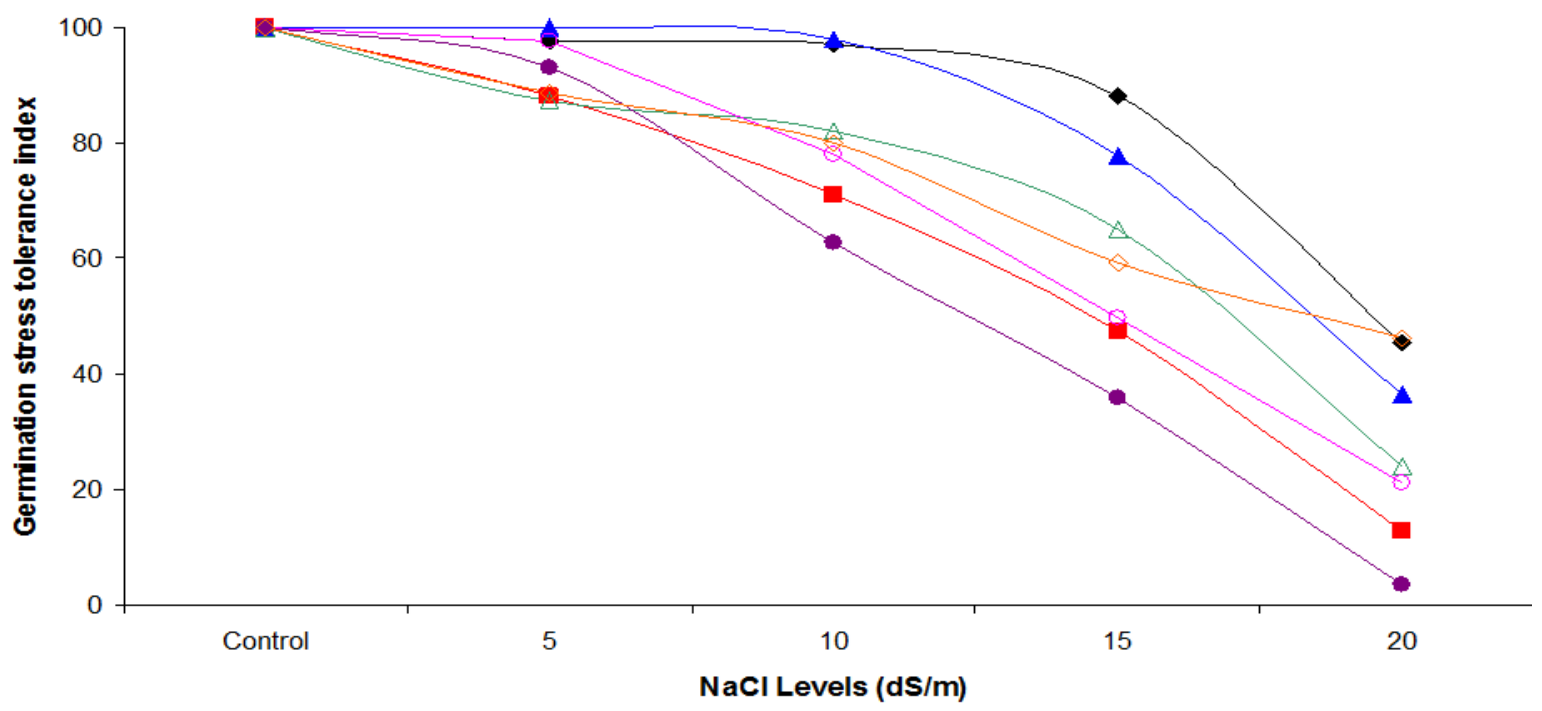

(b)

Figure 1 Changes in vigor index (a) and germination stress tolerance index (b) of pepper cultivars affected by $\mathrm{NaCl}$ levels

Seedling length and seedling fresh weight were severely inhibited by $\mathrm{NaCl}$ levels. The inhibitory effect of $\mathrm{NaCl}$ was more prominent in cvs. BT-Burkalem, Yalova Yağlık and BT-İnce Sivri. The cultivars BT Burli and BTBurdem with high germination performance produced more vigorous seedling growth under salinity. These findings were in agreement with the results of Chartzaulakis and Klapaki (2000), Aktas et al. (2006), Yıldırım and Güvenç (2006) and Zhani et al. (2012) who found the adverse effects of salinity on seedling growth of pepper cultivars. Y1lmaz et al. (2004) emphasized seedling characteristics of pepper cultivars were severely deteriorated by salinity depending on growth stages.

In conclusion, germination stress tolerance index should be suggested for determining salinity tolerance level during germination stage and predicting seedling growth performance of pepper seeds.

\section{References}

Aflaki F, Sedghi M, Pazuki A, Pessarakli M. 2017. Investigation of seed germination indices for early selection of salinity tolerant genotypes: A case study in wheat. Emirates Journal of Food and Agriculture, 29(3): 222-226.
Ahmad S, Ahmad R, Ashraf MY, Ashraf M, Waraich EA. 2009. Sunflower (Helianthus annuus L.) response to drought stress at germination and seedling growth stages. Pak. J. Bot., 41(2): 647-654

Aktas H, Abak K, Cakmak I. 2006. Genotypic variation in the response of pepper to salinity. Scientia Horticulturae, 110: 260-266.

Al-Ansari F, Ksiksi T. 2016. A quantitative assessment of germination parameters: the case of Crotalaria Persica and Tephrosia Apollinea. The Open Ecology Journal, 9: 13-21.

Almansouri M, Kinet JM, Lutts S. 2001. Effect of salt and osmotic stresses on germination in durum wheat (Triticum durum Desf.). Plant and Soil, 231: 243-254.

Bethke PC, Drew MC. 1992. Stomatal and non-stomatal components to inhibition of photosynthesis in leaves of Capsicum annuum during progressive exposure to $\mathrm{NaCl}$ salinity. Plant Physiol., 99: 219-226.

Chartzoulakis K, Klapaki G. 2000. Response of two greenhouse pepper hybrids to $\mathrm{NaCl}$ salinity during different growth stages. Scientia Horticulturae, 86: 247-260.

Foolad MR, Lin GY. 1997. Genetic potential for salt tolerance during germination in Lycopersicon species. HortScience, 32: 296-300.

Foolad MR, Hyman JR, Lin GY. 1999. Relationships between cold- and salt-tolerance during seed germination in tomato: Germplasm evaluation. Plant Breeding, 118(1): 45-48. 
Gunes A, Inal A, Alpaslan M. 1996. Effect of salinity on stomatal resistance, proline and mineral composition of pepper. Journal of Plant Nutrition, 19: 359-396.

ISTA. 2003. International Rules for Seed Testing. International Seed Testing Association, Switzerland.

Murillo-Amador B, Troyo-Dieguez E, Lopez-Cortez A, Jones HG, Ayala-Chairez F, Tinoco-Ojanguren CL. 2001. Salt tolerance of cowpea genotypes in the emergence stage. Aust. J. Exp. Agric., 41: 81-88.

Okçu G, Kaya MD, Atak M. 2005. Effects of salt and drought stresses on germination and seedling growth of pea (Pisum sativum L.). Turk. J. Agric. For., 29: 237-242.

Pascale SD, Ruggiero C, Barbieri G, Maggio A. 2003. Physiological responses of pepper to salinity and drought. J. Amer. Soc. Hort. Sci., 128: 48-54.

Salehzade H, Shishvan MI, Ghiyasi M, Forouzin F, Siyahjani AA. 2009. Effect of seed priming on germination and seedling growth of wheat (Triticum aestivum L.). Res. J. Biol. Sci., 4(5): 629-631.
Shahverdikandi MA, Tobeh A, Godehkahriz SJ, Rastegar Z. 2011. The study of germination index of canola cultivars for drought resistance. Int. J. Agron. and Plant Prod., 2(3): 89-95.

Turhan A, Şeniz V. 2010. Farklı tuz konsantrasyonlarının Türkiye'de yetiştirilen bazı domates genotiplerinin çimlenmesi üzerine etkileri. U.Ü. Ziraat Fakültesi Dergisi, 24(2): 11-22.

Yıldırım E, Güvenç İ. 2006. Salt tolerance of pepper cultivars during germination and seedling growth. Turk. J. Agric. For., 30: 347-353.

Yilmaz K, Akınc1 EI, Akinci S. 2004. Effect of salt stress on growth and $\mathrm{Na}$, K contents of pepper (Capsicum annuum) in germination and seedling stages. Pak. J. Biol. Sci., 7: 606610.

Zhani K, Elouer MA, Aloui H, Hannachi C. 2012. Selection of a salt tolerant Tunisian cultivar of chili pepper (Capsicum frutescens) Eurasia J. Biosci., 6: 47-59. 